\title{
Enhance Balanced SEED with BEST ACTIONS
}

\author{
Orasa Suksawang
}

Geography Department, Social Sciences Faculty, Kasetsart University, Thailand

Copyright $(2016$ by authors, all rights reserved. Authors agree that this article remains permanently open access under the terms of the Creative Commons Attribution License 4.0 International License

\begin{abstract}
This research applied feedback loops of sustainable resource management system as a framework of an integrated curriculum "BEST ACTIONS" for lifelong learning, and training the trainers in low carbon communities, aiming to transfer a sustainability concept into practice. The curriculum comprises interconnected knowledge topics, displayed in the loops, relating to economic and environmental problems that need science and technology approach to create "BEST Credit" and management skills needed to achieve "BEST Climate" and solving social problems that need holistic thinking, for multi-problem solving, approach to realize best ACTIONS. All knowledge was integrated and transferred, through seven activities in two-day workshops to communities at the Nakhon Phanom province in Thailand, under the project titled: "Biomass to Energy and Biochar Community: BEBC" (2013-2015), funded by the Energy and Environment Partnership with Mekong (EEP Mekong). At present, the participants have adopted the sustainability concept in community business, dealing with biomass and biochar. The design of "BEST ACTIONS" and its applications in workshops and real life practices are discussed.
\end{abstract}

Keywords Integrated Curriculum, Lifelong Learning, Sustainability, Biomass, Biochar, Business

\section{Introduction}

\subsection{Sustainable Development Concept}

"Sustainability" was first used in German forestry in 1713 focusing on the conservation of forests - the balance between old trees harvested and young trees replaced. The growth of population with increasing of resource use resulted in awareness of sustainable consumption. After World War II, from 1950s, the drastic growth of industrial and commercial sectors caused environmental crisis [1]. Twenty years from 1972 to 1992 Sustainable Development (SD) concept was driven by UN through conferences starting from the need to include an environmental issue in development planning. The United Nations Environmental Program (UNEP) was created for encouraging the nations to implement this concept. SD was defined by the World Commission on Environment and Development known as
Brundtland Commission - "the development that meets the needs of the present without compromising the ability of future generations to meet their own needs" [2]. In 1997 Kyoto conference on climate change, a general framework known as Kyoto Protocol was formulated, resulting in commitments of industrialized countries to cut emissions of greenhouse gas to the atmosphere. In 2000 the Millennium Development Goals (MDGs), outlined the year 2015 as a timeframe for integrating principles of SD into country policies - the balance between the economic, social and environmental pillars - using 1990 as a benchmark [3]. UN conference in September 2015- "Implementing the SDGs: Getting Started"- - still confirmed triple win pillars declared in MDGs, and set up an agenda to eradicate global poverty and hunger by 2030 [4]. To achieve this goal, the SD concept should be learnt and practiced at community level as will be described next.

\subsection{Create Sustainable Development from "SEED" of the Project}

"SEED" in this paper stands for Social-EconomicEnvironmental Development aiming to communicate that in order to balance between the development/growth of the three pillars or three-win situations, we should start from the seed level-good seeds foster strong growth of plants, and healthy plants are developed from strong seeds. The balanced "SEED" was applied for implementation at community level under the two-year project (2013-2015) titled: Biomass to Energy and Biochar Community (BEBC) at Nakhon Phanom province in Thailand partly funded by the Energy and Environment Partnership-Mekong (EEPMekong). The Project included the interconnected elements/problems to be solved in one system (Figure 3) environmental pillar: infertile soil and emissions from agriculture; economic pillar: poverty, and social pillar: human and social capitals to manage a balanced SEED. This project helped solving more problems at the same time: alternative energy, greenhouse gas mitigation, land resources and rural poverty, improving the conditions in communities and households. At community scale, crop-wastes from farmlands became fuels for power generation while the bio-char and ash residues were returned back to farmers for carbon sequestration and soil improvement, in an exchange scheme. It also introduced a local carbon credit concept. 


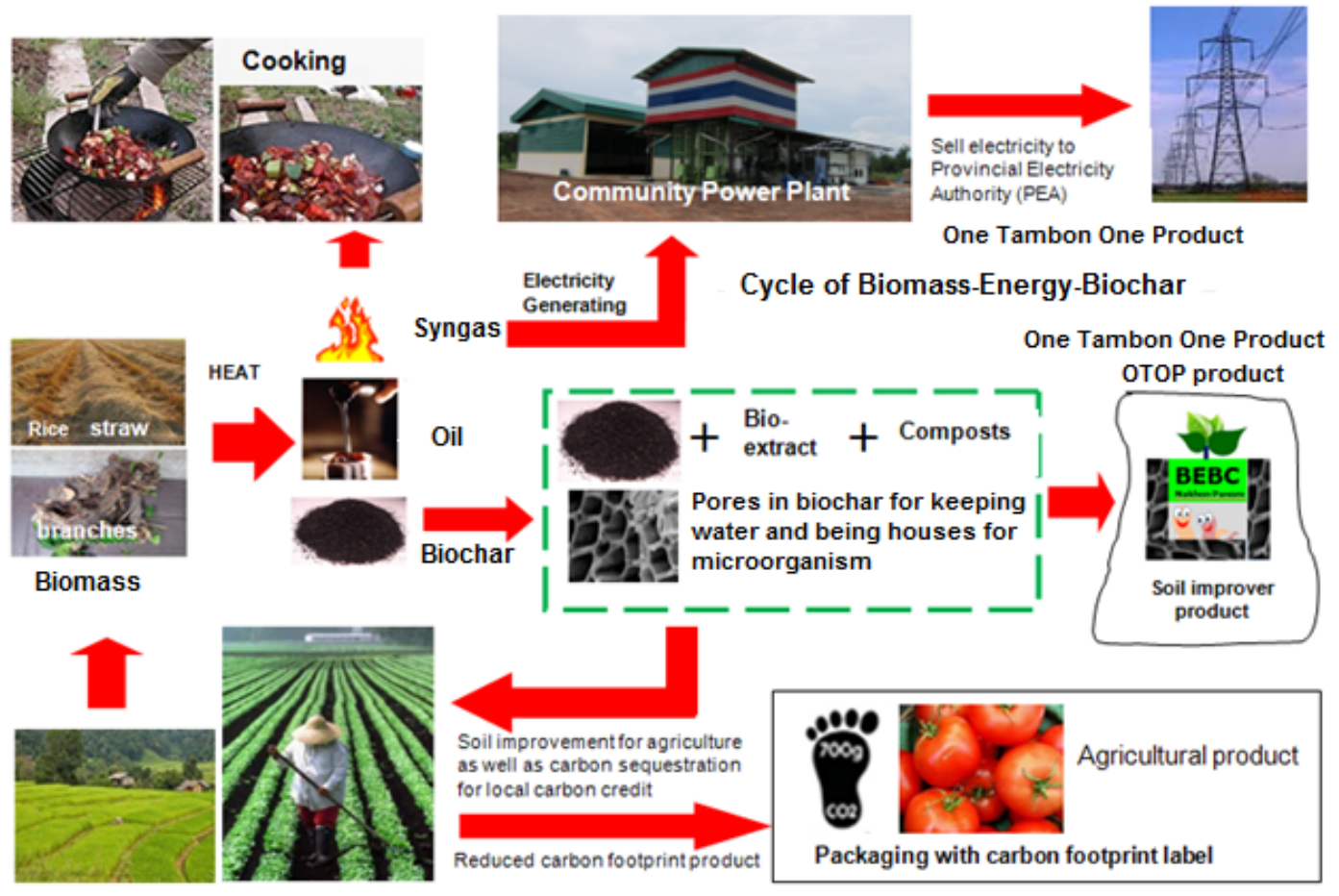

Figure 1. BEBC Project Framework

Moreover, food processed from crops using biochar could be labeled with a low carbon footprint for consumption incentives/promotion of "green" products as shown in Figure 1. The project has been led by Kasetsart University Research and Development Institute (KURDI), in collaboration with three partners -Nakhon Phanom Provincial Administrative Organization (NKP PAO), Supreme Renewable Energy Co., Ltd (Supreme), and Ms. Sornwan Sirisuntarint, and additional two strong Supporter Agents-The Provincial Government and the Communities. The target site was Plapak District, Nakhon Phanom Province in Thailand as shown in Figure 2.
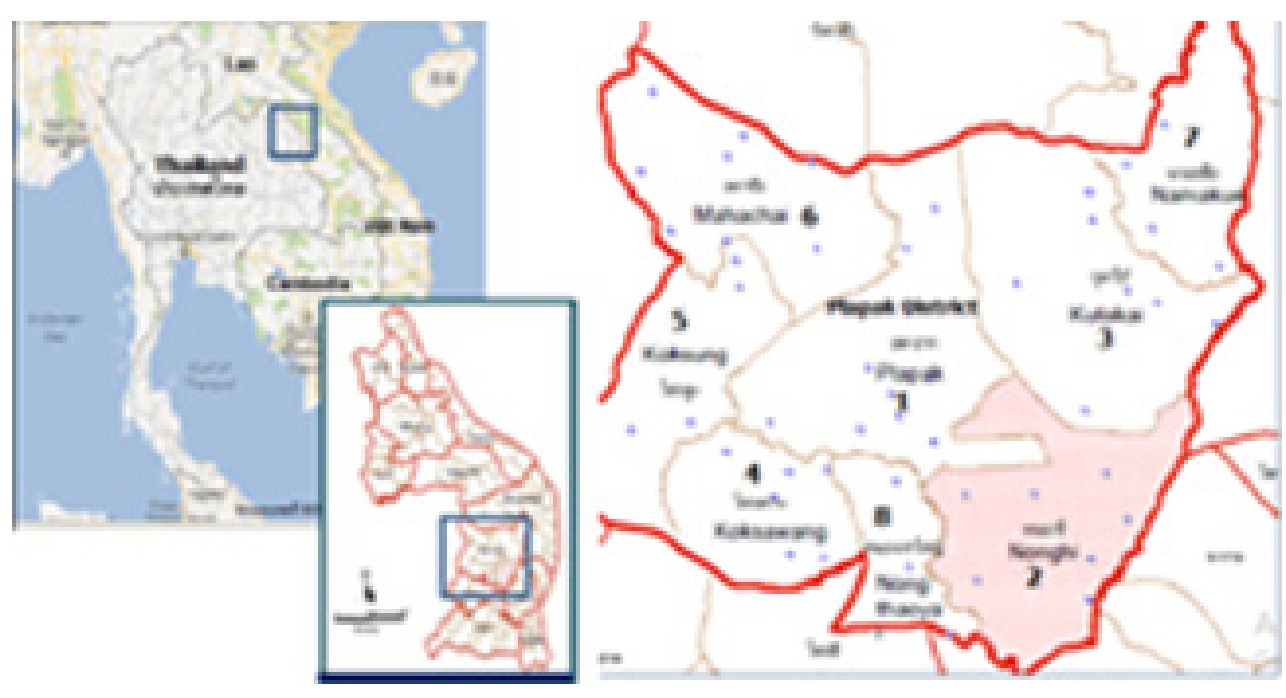

Project boundary/Plapak district, Nakhon Phanom

province, Thailand, Area: $547 \mathrm{sq} . \mathrm{km} 2$

Population: 53,688 prs., Households: 16,187 units

\section{Sub-district boundary}

\section{Sub-district where power plant is located}

Figure 2. Map of the Project Site 
In order to achieve the project Outputs under sustainability, BEST ACTIONS, an integrated curriculum of lifelong learning and "training the trainers" for low carbon community, designed by the author, was used as central to enhance the balanced "SEED" and as a goal for project implementation including training in the workshops and practices in daily lives. In this paper only BEST ACTIONS will be focused upon in terms of design and applications in the BEBC project. Thus the objectives of this paper are to describe how "BEST ACTIONS" was designed and managed into activities in the workshops; and to assess its applications in the targeted communities.

\section{Material and Methods}

\subsection{Development of BEST ACTIONS Concept}

The term "BEST ACTIONS" has been used for two purposes; one as a slogan for community actions, since the meaning can be understood by the words themselves; another as key topics for training in workshops and for lifelong learning, since each character stands for integrated topics of knowledge as shown in Table 1. The knowledge topics of the program were categorized, based on the project framework, into three groups - the first group included topics relating to economic and environmental pillars - Biomass, Energy, Soil, Technology and Agriculture - requiring Science and Technology approaches; the second group included topics related to the social pillar - Community, Teamwork, Image, Obligation and Network - requiring Management skill approach; the last group was an integration of both groups - Sustainability — requiring Holistic view approach or System approach (feedback loops of BEST ACTIONS).

Table 1. A Structure of BEST ACTOINS for Low Carbon Community

\begin{tabular}{|c|c|c|}
\hline Topics & Key Knowledge for Learning/Training & Approaches \\
\hline Biomass & $\begin{array}{l}\text { Biomass-Biochar-Business; what are biochar benefits, how to convert biomass to biochar and } \\
\text { make business, applications }\end{array}$ & \multirow{5}{*}{$\begin{array}{l}\text { Sciences and } \\
\text { Technology, } \\
\text { Experiment, } \\
\text { Conflict between } \\
\text { economic and } \\
\text { environmental } \\
\text { development and } \\
\text { how to balance it. }\end{array}$} \\
\hline Energy & $\begin{array}{l}\text { Energy-Environment; renewable energy for electricity generation and for low carbon community, } \\
\text { biomass gasification stove making }\end{array}$ & \\
\hline Soil & Soil; how to maintain soil fertility with biochar, relationship between soil and agricultural yield & \\
\hline Technology & $\begin{array}{c}\text { Technology-Trade; what carbon negative technology, carbon trading, and carbon footprint are. } \\
\text { What are their associations? }\end{array}$ & \\
\hline Agriculture & Agricultural product with carbon footprint label. Why? How? Agreement & \\
\hline Community & $\begin{array}{l}\text { Community-Carbon credit- Carbon footprint; how to become a low carbon community, how to } \\
\text { establish a community enterprise }\end{array}$ & \multirow{5}{*}{$\begin{array}{l}\text { Management of } \\
\text { integrating } \\
\text { environmental } \\
\text { protection in } \\
\text { economic and social } \\
\text { development }\end{array}$} \\
\hline Teamwork & $\begin{array}{l}\text { Team-Tradition-Trust-Tacit; tradition, trust in teamwork, tacit knowledge transfer within } \\
\text { teamwork, trademark }\end{array}$ & \\
\hline Image & Image-Idea; idea to create the brand, low carbon community image & \\
\hline Obligation & Social responsibility for environment, global warming caused by agricultural sectors, soil crisis & \\
\hline Network & Network-Native-Nation; networks for marketing; native resource management & \\
\hline Sustainability & $\begin{array}{l}\text { Sustainability concepts and practices of energy consumption, interactions between BEST } \\
\text { ACTIONS, CREDIT \& CLIMATE. Case studies }\end{array}$ & $\begin{array}{l}\text { Holistic View/ } \\
\text { Integration }\end{array}$ \\
\hline Practices & Community Skills' Expectation & Skills \\
\hline $\begin{array}{l}\text { Observing } \\
\text { Changes and } \\
\text { Interactions } \\
\end{array}$ & $\begin{array}{l}\text { Management of community resources and business; } \\
\text { production of biochar for soil improvement in agriculture and selling; production of biomass } \\
\text { gasification stoves for households }\end{array}$ & $\begin{array}{l}\text { Holistic view, } \\
\text { Prediction }\end{array}$ \\
\hline Practices & Community Attitudes' Expectation & Attitudes \\
\hline $\begin{array}{l}\text { Cause-effect } \\
\text { relationship }\end{array}$ & $\begin{array}{l}\text { Creative enterprise using renewable resources with carbon negative technology; and moderate } \\
\text { energy consumption are keys for low carbon community and sustainability }\end{array}$ & $\begin{array}{l}\text { Holism, Renewable, } \\
\text { Recycle. . }\end{array}$ \\
\hline
\end{tabular}




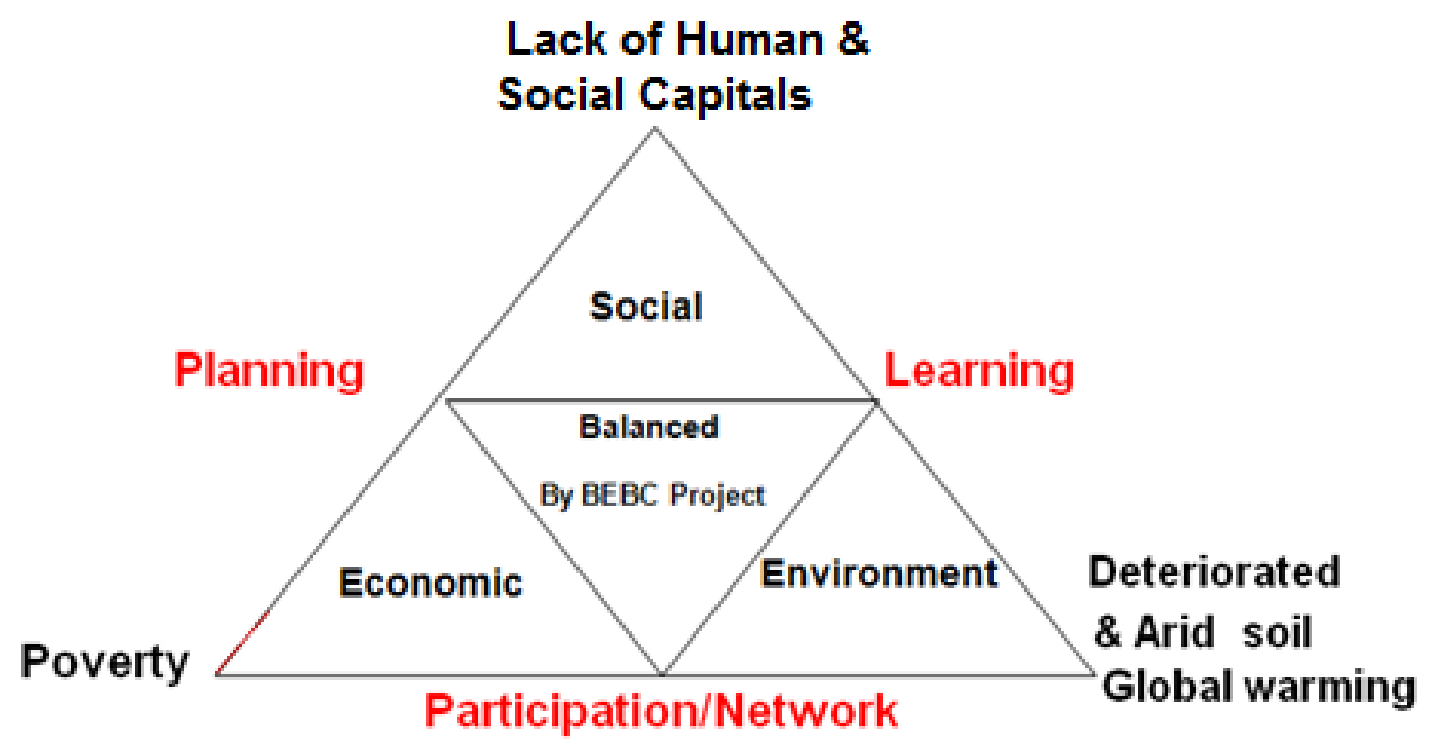

Figure 3. Problems of three-pillar to be solved by the project

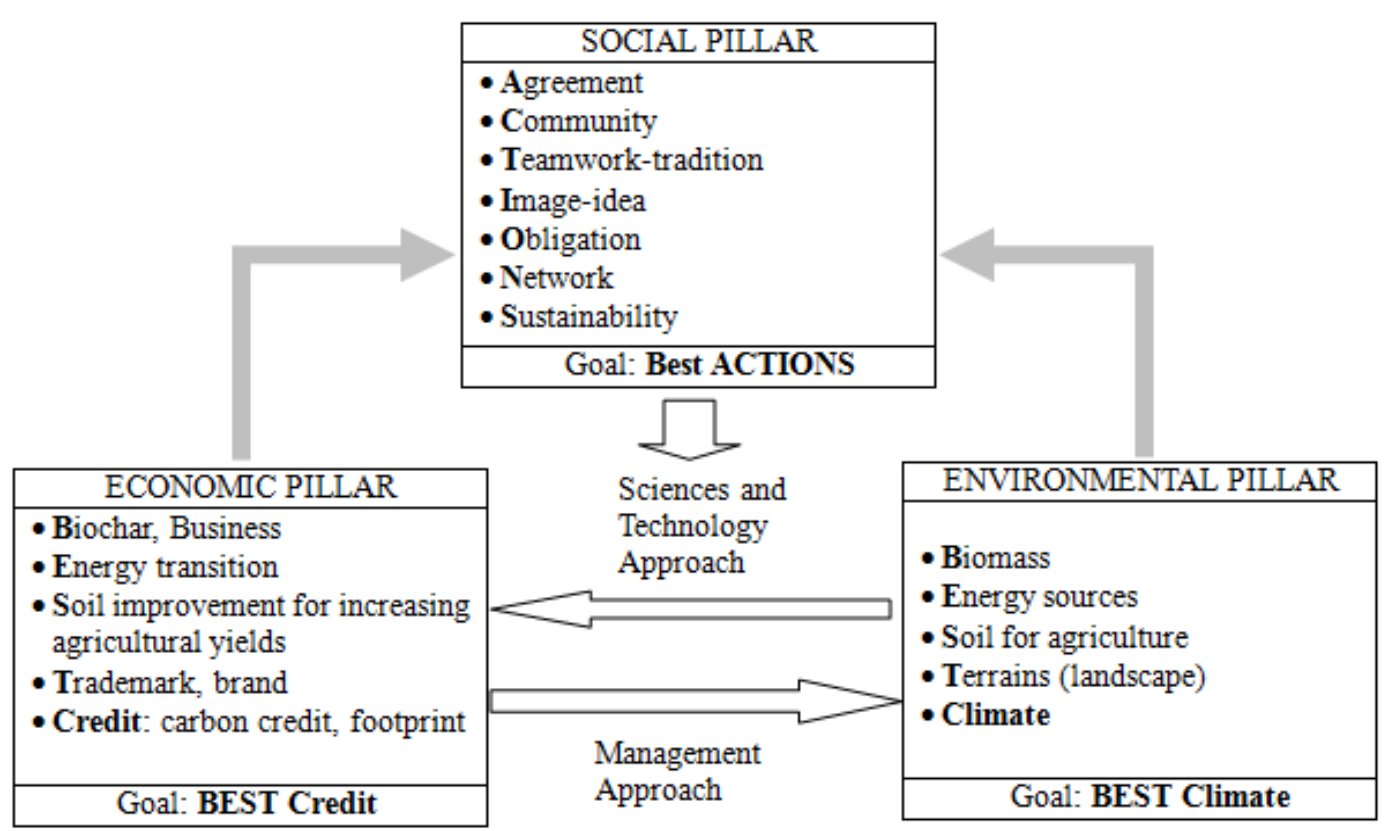

Figure 4. Conversion of three-pillar problems to three goals under sustainability

\subsection{Media Development and Preparation}

The heart of media design was to invent the learning tools that could develop holistic visions and thinking process towards sustainable development - the trainees could develop their thought through cause-effect relationships across various elements within the system while the trainers could learn the trainees' thought and find out the gaps among the trainees, and between the trainees and the trainers, through feedback loops of elements presented by the trainees. These gaps would be the guidelines for adapting the management of the training process and lifelong learning approaches. Figure 4 presents the feedback between the three-pillar goals: Best ACTIONS, BEST Credit and BEST climate for solving the problems in social, economic and environmental development as shown in Figure 3. ACTIONS and BEST are the topics to be learnt for goals' achievement (Figure 4).

The learning materials in BEST ACTIONS comprised 4 main forms: 1) BEST ACTIONS Manuals consisting of a Lesson Plan for trainer/teacher, Exercises for trainees/ students, and Materials for learning/training; 2) Sets of system elements, based on topics, to be trained in the holism concept such as in Activity 1: Biomass - Energy - Biochar (Figure 5-right) and Activity 3: Gasification Power Plant (Figure 7); 3) A set of kits, for a trial on converting biomass 
to energy and biochar, in Activity 2 (Figure 6); and 4) Songs [7], written by the author: BEBC, Biomass, Biochar, Energy choice, Sustainable leader, Smart teamwork, Powerful community and Sustainability, embracing contents of Science, technology and principles of sustainability to be learnt, practiced with pleasure and easy to remember. The song melodies were developed by Mr. Wacharin Vises, a teacher of Dhamakhosit School; local musical instrument was Vina, played by Mr. Boonlert Unchai, a teacher of Thansamai School and sung by teachers in Plapak District. Only Activity 1-3 in the first day of the workshop will be presented.

Feedback loops in Figure 5-left [5, 6] is the solutions of Activity 1, including the problems and choices for solving, for trainees to be learnt: block 1 displays the balance between plants and $\mathrm{CO}_{2}$ being disturbed by biomass burning and decomposing in the agricultural sector, resulting in an increase of greenhouse gas (GHG) emissions; and block 3 illustrates the uses of chemical fertilizers for soil improvement and tillage practices before cultivation also creating more GHG emissions.. Both block 1 and block 3 are existing problems in agricultural development resulting in soil deterioration, low agricultural yields, poverty, and disasters due to the global warming effect shown in block 4 . The solution for this situation is to change performance in block 1-burning and decomposing biomass wastes of agriculture - to block 2 - converting biomass to energy and biochar for sinking in the soil for soil improvement and carbon sequestration for emission reduction, while energy/gas can be fuel for cooking at household level, or for generating electricity in a power plant. This could result in the rise of soil fertility and agricultural yields, while reducing the use of chemical fertilizers, and reducing poverty (block 3 ) as well as achieving less disaster caused by $\mathrm{CO}_{2}$ emissions (block 4).

\subsection{Activity Assessment Method}

Each activity was assessed based on the following information.

2.3.1 Feedback loops, presented by the trainees of each activity's topics, were analyzed by the trainers to find out the gap in the thinking process among the trainee groups as well as between trainees and trainers.

2.3.2 A questionnaire comprising a set of variables relating to each activity was used for measuring the knowledge and skill gained, and attitudes adopted towards sustainability

2.3.3 Trainees' participations during performing each activity were observed by the mentors.

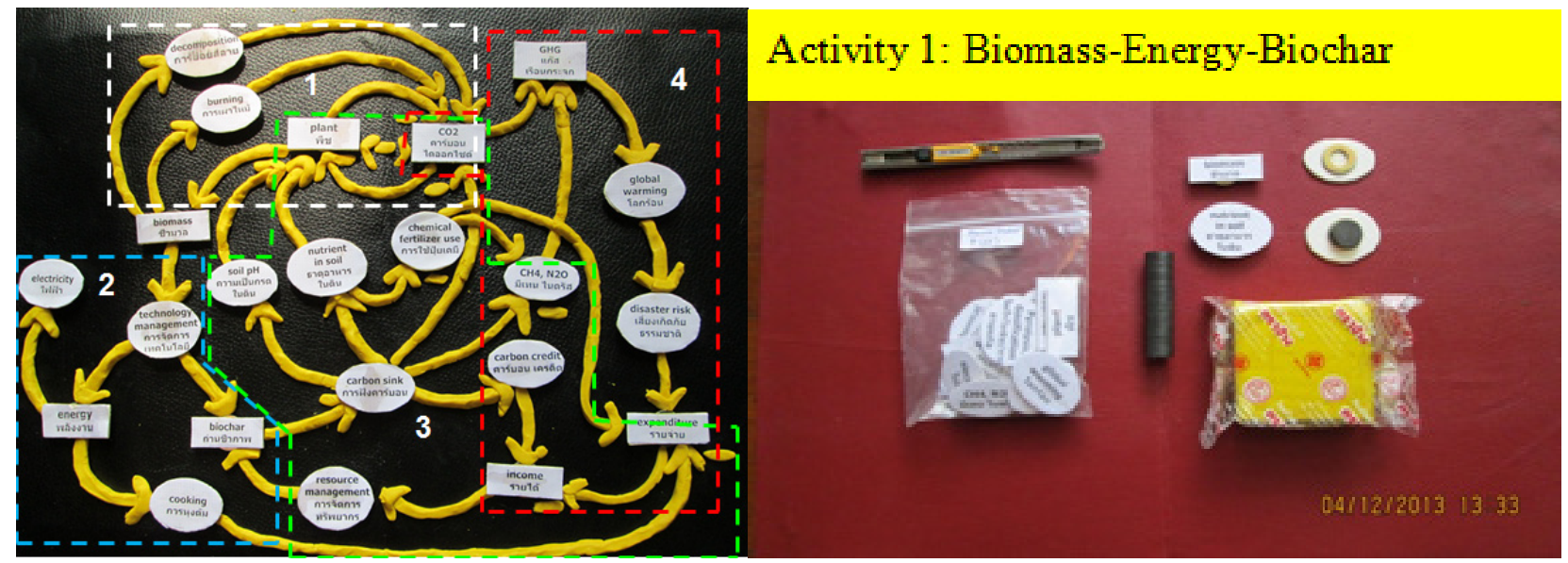

Figure 5. An answer of feedback loops for Activity 1 (left) and equipment (right) for trainees to formulate the feedback loops based on their experiences and manual instruction 


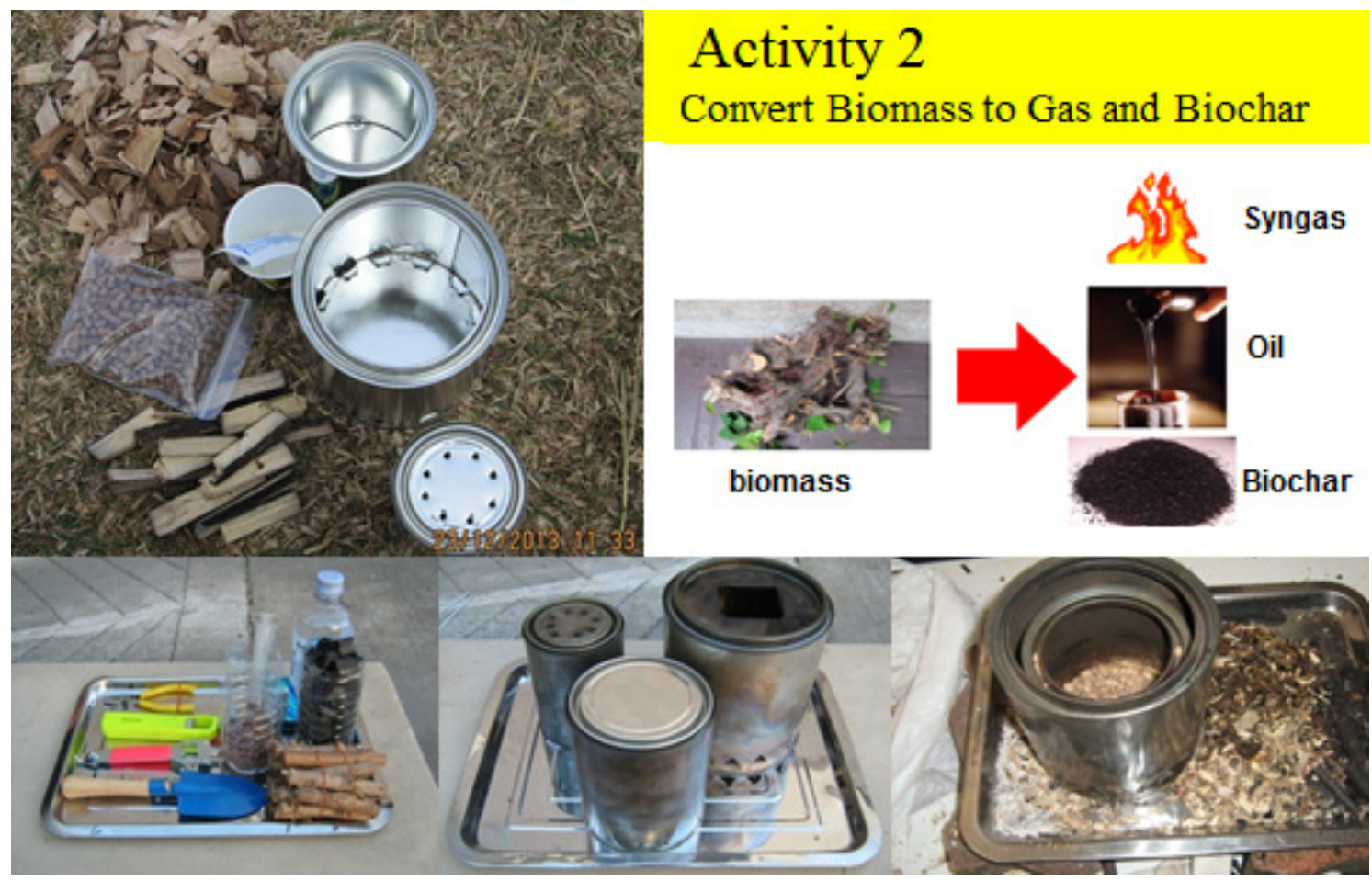

Figure 6. Kits for trial on converting biomass to energy and biochar in Activity 2

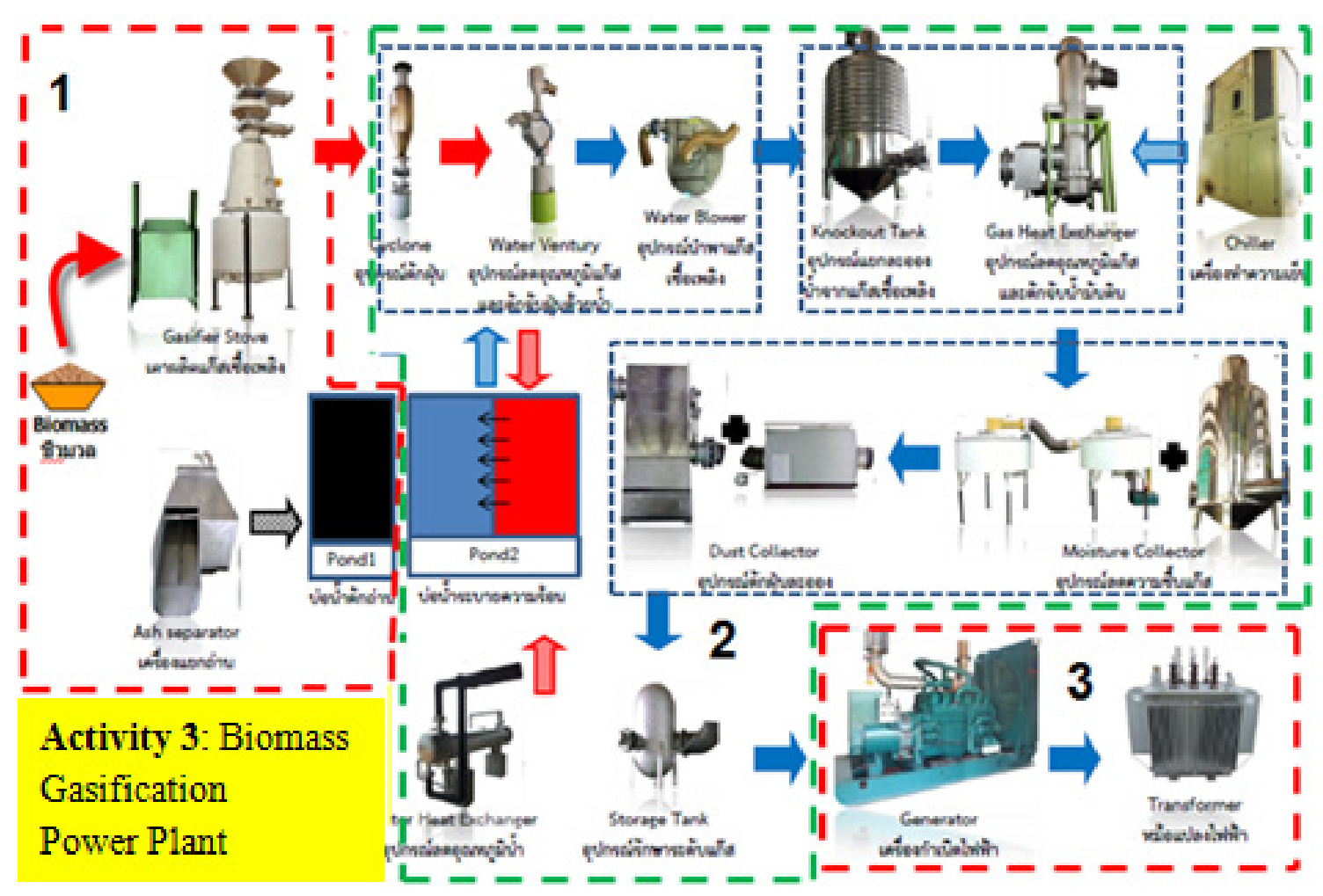

Figure 7. Elements in Power Plant for trainees to formulate the process of equipment installation 

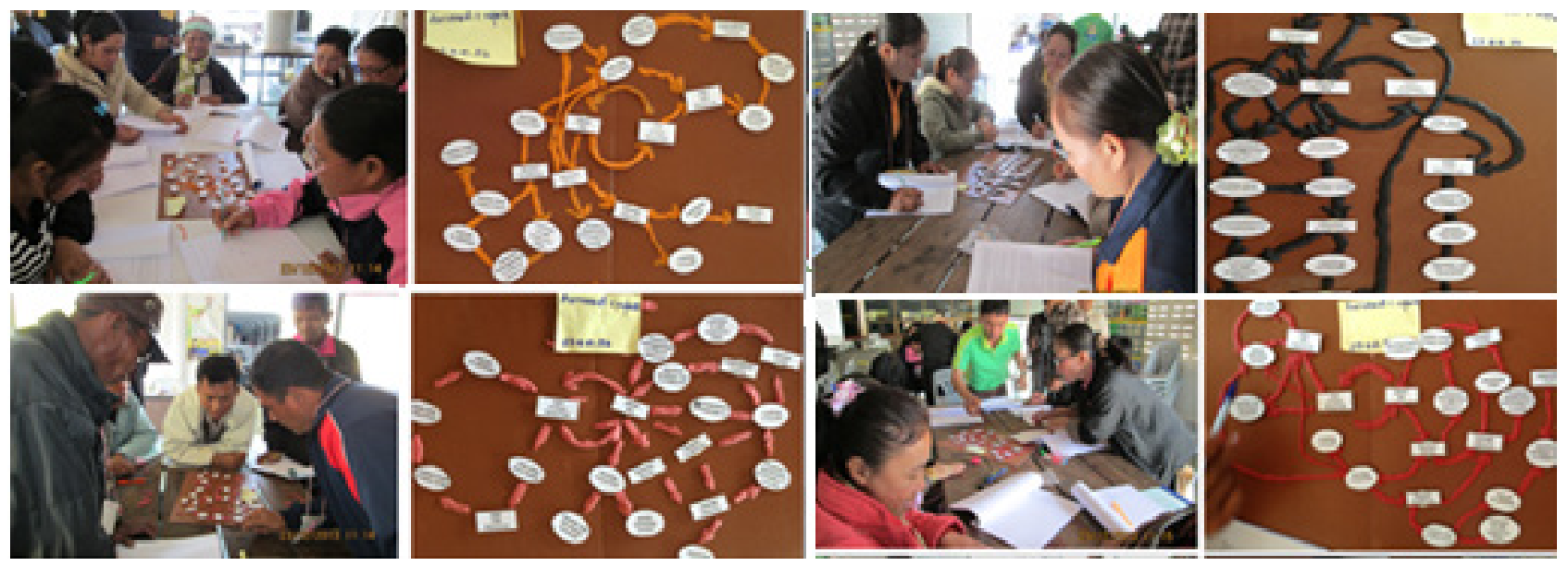

Figure 8. Activity 1: Biomass-Energy-Biochar system formulated by trainees in the $1^{\text {st }}$ Workshop, 25-26 Dec. 2013

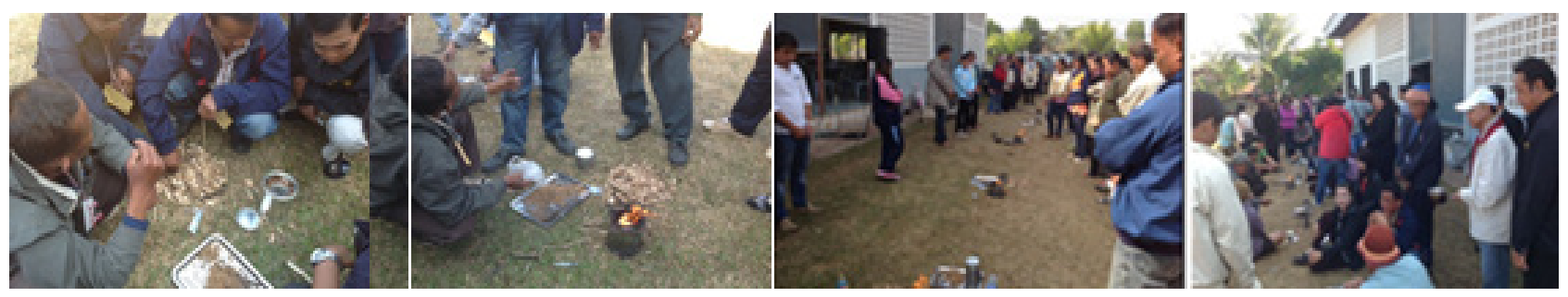

Figure 9. Activity 2: Trials on converting biomass to gas and biochar
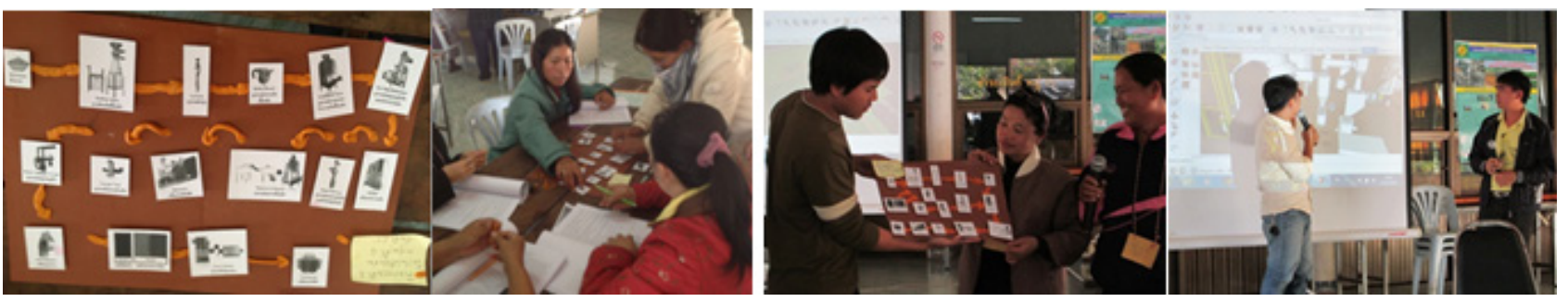

Figure 10. Activity 3: Installation of Power Plant equipment

\section{Results}

\section{Applications and Assessments of BEST ACTIONS in Workshops and in Real Life Practices}

Five Two-day BEST ACTIONS workshops were organized for training the trainers, which included about 250 participants from six target groups: farmers, local authorities, officials, informal leaders, school teachers, and monks. The first day focused on thinking development in science and technology while the second day inspired management approach for human and social capital development. Each trainee received an exercise manual including instructions and descriptions of variables used in each activity for self-study and discussion among group members without lectures. At the end of each session, group representative presented the group work and compared with the answer given and explained by the lecturer/trainer. Each activity ended by altogether singing the song related to the activity for memory and enjoyment. Holistic views and science experiments were found to be developed rapidly in the trainees after actively participating in Activity 1 and 2 (Figure 8,9), performed in the workshop during 3 hours, although they had different backgrounds, ages, educations, jobs and life experiences. Different focus at the problems and methods to solve the problems were found to be the gap between the trainers and the trainees. Most trainees are farmers, they were interested only in soil problems and thought that the uses of chemical fertilizers and burning biomass are the solutions, ignoring the negative impacts to other sectors, while the trainers viewed these practices to be important problems and expected the changes.

However, the trainees realized the relationships and interactions between problems in soil, agriculture, energy consumption, emissions and poverty from sharing ideas and skills in formulating causal loops in Activity 1, and found that technology approached in the trial of Activity 2 - converting biomass to gas for cooking and biochar for soil improvement-was quite simple to practice in real life since biomass wastes were abundant and ignored by people. Activity 3-installing Power Plant Equipment (Figure 
10) - could change their attitudes towards a biomass gasification Power Plant to become positive for environmental protection. After the workshops, the trainees have adopted what they had learnt into practices. At present, they have set up five local training centers by themselves, disseminating the BEST ACTIONS knowledge to people across the district and the province, with technical assistance from the project. Instead of burning and using chemical fertilizers, every day they convert biomass wastes to gas for cooking and use biochar mixed with compost for soil improvement and carbon sequestration for emission reductions. They applied biochar in various field crops - paddy, orchard and vegetables — and had significant findings: no insects, higher yields and toxic free crops. In addition, they also grouped in networks for selling biochar and stoves, invented by the center, for biochar production in the field. They have learned from their own practices that biochar mixed with composts in 800 square meters of paddy field could increase the rice yield by $40 \%$ more than the plot, at the same size and environment, using chemical fertilizers.

\section{Conclusions}

This project is in the final stage but it is in the initial stage at the communities, the seeds of country growth, to expand BEST ACTIONS in order to enhance balanced SEED and achieve UN Sustainable Development Goals in 2030. It is believed that if all people have the same picture of interconnection between the three pillars in the form of feedback loops as shown in this paper, people could better understand how to manage sustainability under three BESTs -BEST ACTIONS, BEST Credit and BEST Climate.

\section{Acknowledgements}

This research is one activity of OUTPUT 4 of Project ID: 4-T-034 (BEBC) research and development oriented, funded by the Energy and Environment Partnership with Mekong from 1st September 2013 to 31st December 2015.

\section{REFERENCES}

[1] Jacobus A. Du Pisani. Sustainable Development- Historical Roots of the Concept, Environmental Sciences, 3(2), 83-96, 2006. Online available: http://www.tandfonline.com

[2] UN (General Assembly). Our Common Future. Oxford: Oxford University Press, 1987.

[3] Bâc Dorin, Paul. A History of the Concept of Sustainable Development: Literature Review. Annals of the University of Oradea, Economic Science Series, 17 (2), 577-579, 2008.

[4] UN (General Assembly). Draft outcome document of the United Nations summit for the adoption of the post-2015 development agenda.2015.

[5] Suksawang, Orasa. Biochar Technology: An Approach to Solving Global Warming, Soil and Poverty in Agri-sector. Proceedings of Global Warming: Bio-diversity and Sustainable Uses, Paper presented at Kasetsart University, Kampangsan Campus, Nakorn Prathom Province, 5-6 November 2009, 172-184, 2009.

[6] Suksawang, Orasa. Biochar: Carbon Negative Technology. In Fostering Economic Growth through Low Carbon Initiatives in Thailand. Bangkok: Chula Global Network, Chulalongkorn University, 139-152, 2011.

[7] Melody in Education. Online available: https://sites.google.com/site/Thailandbiochar/ learning-center.2015 